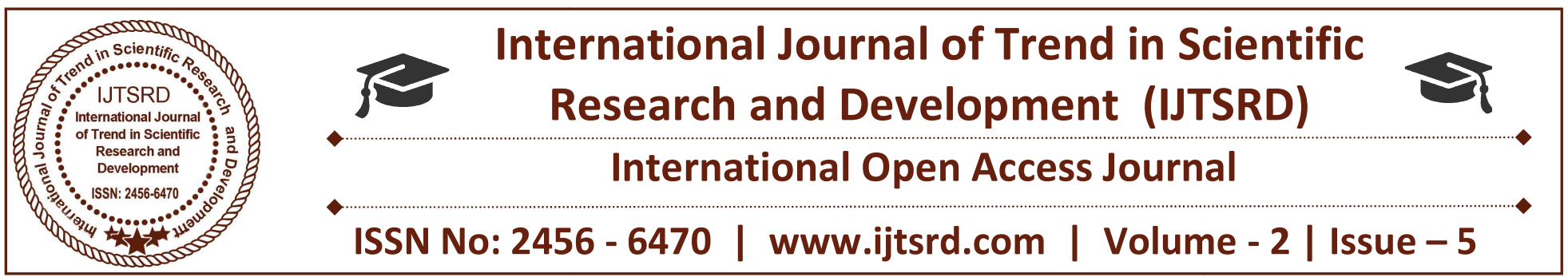

\title{
Women in Pre Independence and Post Independence
}

\author{
Attendra Nigam \\ B.B.A., L.L.B (Hons), Indore Institute of Law \\ Indore, Madhya Pradesh, India
}

Women status in India before independence -Women in ancient India were held in high esteem. The position of a woman in the Vedas and the Upanishads was that of a mother (maata) or goddess (Devi). In the Manusmriti, woman was considered as a precious being o be projected first by her father, then by her brother and husband and finally by, her son. With the passage of time, the status of woman was lowered. Muscle power and money power dominated the societies. Since men fought the wars and ran the enterprises of industrial production, they considered themselves superior to woman. In the early Vedic age, girls were looked after with care. They were given the facilities of education. Remarriage of windows was permitted. But in the later Vedic period, daughters were regarded as a source of misery. The practice of polygamy deteriorated the status of woman. Women in the later civilizations were not allowed to go to schools. In the Gupta period, they were allowed to listen to the scriptures. In the medieval period, the practices of purdha system, dowry and sati came into being. Sati and PolyGram

were glorified.. It is thought that the right place for woman ins the home. Her main duty is to cook to all other menial jobs. They are considered fit for producing and bringing up children. Thus, women have been deprived of their rightful place in society and exploitation. has been going on for centuries. The inhuman practice of sati where the wife burns herself alive in the funeral pyre of husband existed through the centuries. Raja Ram Mohan Roy fought against this evil practice and it was finally abolished by Lard William Bentinck in 1829. After the development of science and technology, female foeticide is being practiced on a large scale. This has led to a drop in the female ratio. According to the census 2001, the sex ratio in India is 927 females to 1,000 males. Dowry has become common. The more educated and well employed a groom, the higher is the dowry demand. The birth of a girl child is, therefore, considered inauspicious. In many parts of India, women are viewed as an economic liability despite contribution in several ways to our society and economy. Early marriages lead to teenage pregnancies which often prove risky to both the mother and the child. Rape, sexual harassment, molestation, eve-teasing, forced prostitution, etc are a common affair today. The crime graph against women is increasing at an alarming rate. The condition of an Indian widow is quite deplorable. At home, the woman's contribution towards home as a housewife is not recognized. Sexual harassment at work places is also a common affair. It is a shame that even after over sixty years of independence women are still exploited. The 73rd and 74th constitutional amendments have provided 33 percent reservation for women in the Panchayati Raj System. Women have now started demanding their rights. They want to work side by side with men and contribution towards the social, economic and political development of the society. ${ }^{1}$

Social Reform Movement in India and Role of Women!

The social reformers believed in the principle of individual liberty, freedom, and equality of all human beings irrespective of sex, color, race, caste, or religion. They attacked a number of traditional, authoritarian, and hierarchical social institutions and launched social reform movements to liberate the Indian women from their shackles.

\footnotetext{
${ }^{1}$ ( https://www.scribd.com/document/213644268/WomenStatus-in-India-Before-Independence )
} 
There are two distinct groups of progressive movements aimed at emancipation of Indian women. Both groups recognized the restrictive and coercive nature of the social customs and institutions. One group opposed these customs and institutions as they contradicted the democratic principles of liberty and freedom. This group was called the Reformers.

The other group demanded the democratization of social relations and removal of harmful practices on the basis of revival of the Vedic society in modern India, which according to them, was democratic. This group came to be known as the Revivalists.

\section{Here's how The Status of Women Has Changed In India}

"It is impossible to think about the welfare of the world unless the condition of women is improved. It is impossible for a bird to fly on only one wing." Swami Vivekananda

Women are not born, but made. What better than India to exemplify this statement by Simone de Beauvoir. With the whole world celebrating International Women's Day with great pomp and show, it would be only apt to analyse the position and space Indian women occupy today, and comparing it to the time 60 years ago when the country had just gained independence. With women participating in nationalist movements, to being pushed into the domestic household space, to their resurgence as super-women today, women in our country have seen it all.

There have been innumerable debates about gender in India over the years. Much of it includes women's positing in society, their education, health, economic position, gender equality etc. What one can conclude from such discussions is that women have always held a certain paradoxical position in our developing country.

While on one hand, India has seen an increased percentage of literacy among women, and women are now entering professional fields, the practices of female infanticide, poor health conditions and lack of education still persisting still continue. Even the patriarchal ideology of the home being a woman's 'real domain' and marriage being her ultimate destiny hasn't changed much. The matrimonial advertisements, demanding girls of the same caste, with fair skin and slim figure, or the much criticised fair and lovely ads, are indicators of the slow changing social mores. If one looks at the status of women then and now, one has to look at two sides of the coin; one side which is promising, and one side which is bleak.

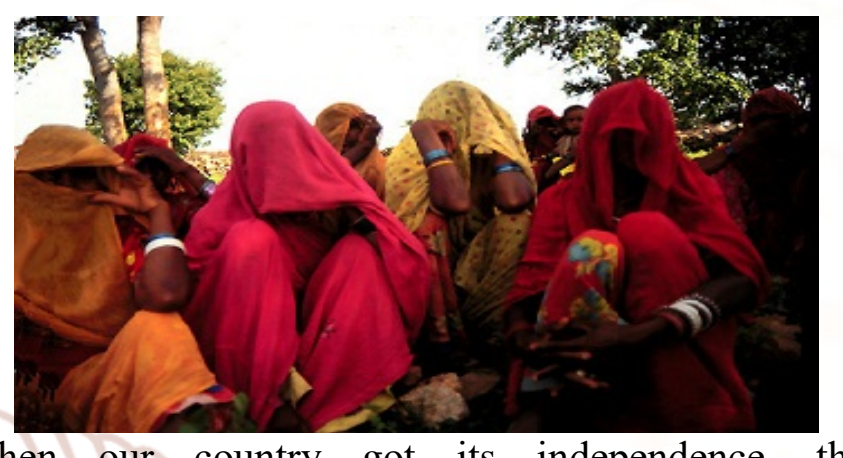

When our country got its independence, the participation of women nationalists was widely acknowledged. When the Indian Constitution was formulated, it granted equal rights to women, considering them legal citizens of the country and as an equal to men in terms of freedom and opportunity. The sex ratio of women at this time was slightly better than what it is today, standing at 945 females per 1000 males. Yet the condition of women screamed a different reality.

They were relegated to the household, and made to submit to the male-dominated patriarchal society, as has always been prevalent in our country. Indian women, who fought as equals with men in the nationalist struggle, were not given that free public space anymore. They became homemakers, and were mainly meant to build a strong home to support their men who were to build the newly independent country. Women were reduced to being second class citizens. The national female literacy rate was an alarmingly low $8.6 \%$. The Gross Enrolment Ratio (GER) for girls was $24.8 \%$ at primary level and $4.6 \%$ at the upper primary level (in the 11-14 years age group). There existed insoluble social and cultural barriers to education of women and access to organised schooling.

A very few were allowed into the public space, which she was expected to manage on her own, while maintaining her domestic role as a homemaker. In spite of the Sharda Act which was passed in the 1950s to raise the marital age limit for girls, child marriage particularly in North India was quite prevalent though the average age at marriage for females was increased to 18. Sprawling inequalities persisted in their access to education, health care, physical and financial resources and opportunities in political, social and 
cultural spheres. It was almost unthinkable for women to have a choice or a say in matters of marriage, career or life. Rather she had no voice at all. The practice of dowry was as common as ever.

\section{Changing status of women after the Independence of India -}

The Gandhian era and the decades after independence have witnessed tremendous changes in the status of women in Indian society. The Constitution has laid down as a fundamental right the equality of sexes. But the change from a position of utter degradation and subjugation of women in the nineteenth century to a position of equality in the middle of the twentieth century is not a simple case of the progress of women in the modern era.

Revolutionary changes have taken place in the position of women in India after independence. The Constitution of India provided for special steps to be taken by the government to improve the condition of women by separate institutions.

A quick and effective change in the status of women was contemplated through social legislations. The Constitution of India guarantees certain fundamental rights and freedom such as protection of life and personal liberty. Indian women are the beneficiaries of these rights in the same manner as the Indian men. Article 14 ensures equality before law and Article 15 prohibits any discrimination. Article 16(a) forbids discrimination in any respect of the employment of office under the state on the grounds only of religion caste, sex, descent, and place of birth, residence or any of them.

In the post-independent India, there are series of laws passed for the upliftment of women. These legislations have been brought in order to give equal rights and privileges with men, to eliminate discriminations against women, remove inequality between sexes, and remove external barriers coming in the way of their self-realisation and development.

Some important Acts passed for the upliftment of women are:

\section{The Hindu Marriage Act of 1955:}

This Act provided equal rights to women to obtain a divorce and also maintenance in certain cases.
2. The Hindu Adoption and Maintenance Act of 1956:

By virtue of this Act, a woman can adopt a boy or a girl as her son or daughter.

\section{The Hindu Minority and Guardianship Act of 1956:}

This Act provides that a woman is entitled to act as the natural guardian of her minor children.

4. The Hindu Succession Act of 1956: As a result of this Act, a woman has got equal rights in the inheritance of family property. This Act is a landmark in the history of Hindu law.

\section{The Hindu Women Right to Property Act of 1973:}

This Act has given more facilities to women. According to this Act, the daughter, the widow, and the mother can inherit property of the deceased simultaneously. Now women will hold her property absolutely with full right to sell, mortgage, and dispose of as she desires. But according to the Hindu Succession Act, 1956, the woman has only to enjoy her husband's share in coparcenaries property for her life time without any right to alienate property.

6. The Dowry Prohibition Act of 1961: According to this Act, taking or demanding dowry is an offence punishable by imprisonment and or fines.

7. The Equal Remuneration Act of 1976: This Act does not permit wage discrimination between male and female workers.

Besides legislations, education was also regarded as an important factor in raising the status of women in society. Therefore, active steps were taken to promote women's education. Immediately after independence it was realised that unless half of our population are exposed to educational process, modernisation of our society would be a distant dream. Various Committees and Commissions emphasised the need for equalisation of educational opportunities.

This led to opening of different schools and colleges, especially for women. 
However, the absence of any economic compulsion was in fact one of the main reasons for the slow progress of women education till seventies. There is a gradual change among the women that in order to make a decent living and to assert their rights and privileges and to become economically independent, they must acquire proper skill through education.

Hence, there has been a constant rise of women ratio in the field of higher education.

There has been a remarkable increase in the number of women getting out of the four walls of the household and becoming workers in both cities and villages, according to the 1991 census report. Job opportunities outside the family, economic hardship and social situation have encouraged women to take up employment outside the family. The attitudes of women's relatives towards women's employment, women's own preference for employment are now quite different from earlier beliefs. People are now in favour of women employment.

Today, the centre of production is located outside the family, economic conditions demand participation of women with men in the production process. This has enhanced the status of women in the family as well as the society.

According to the report of the Committee on the Status of Women in India (1974), the number of female employees in the categories of professional, technical and related workers, primary and middle school teachers has been continuously rising since 1960. The Director General of Employme as the four occupations.

In the political field, women now enjoy equal rights with men. The two important rights in the political field sanctioned to women by Indian Constitution are: female enfranchisement and eligibility for the legislature. Prior to independence, when the elections were held in 1946 for constitutional assembly, many prominent women of Indian like Sarojini Naidu, Hansa Meheta, Renuka Rai and others were elected. In the first general election held in 1952, several women contested for the Lok Sabha.

After independence more women have joined different political parties. Some of them have captured seats of power as Chief Ministers, Cabinet Ministers, Deputy Ministers and Ministers of States.
Now all the political parties have a woman's cell or wing and some women leaders are in the position of president or secretary of party. Women of different parties are actively participating in campaigning and organising meetings at the time of elections. The families are always helping women to have a smooth entry in politics. Now politics is not the exclusive domain of men.

Many changes have taken place with respect to social life of Indian women. The 'new life' in city has altered the family relations. Social life of women has been altered because the husband and wife have begun to share a common social life which was not found in traditional family.

Attitude towards segregation of sexes has also been changing. Coeducation has created an opportunity for intermixing of boys and girls. During leisure the women visit their friends' house. Boys take girls out to entertain them by taking to movies, restaurants and picnic.

Industrialisation has not only affected the joint family system, but also the relationship between the husband and the wife. The position of a woman as consultant is found in most families where she shares the responsibility of making the major family decisions with her husband or father. Now authority vests not only on eldest male but also on females.

It is well known that the freedom movement in India generated great awareness among women about their social right and their social responsibilities in the larger soc.al order one result of this was the manifestation of a new creative urge among women in post-independent India.

The status of women and their social relationship as necessitated by the new social, political and economic organisation in society has come out through the routine factors of social change.

Undoubtedly in the period before 1947 there was a considerable change in thinking, outlook and value of Indian women. Subsequently Indian women have gradually moved towards self-reliance and independence. The status of Indian women through the ages has been changing and the status, which was lost during the middle ages and earlier parts of 19th century, has been regained somewhat. It appears that the status of women has gone high in India. 
However the real position is that a large majority of women in the villages or women of low caste still suffers from injustice and inequalities. ${ }^{2}$

2

(https://www.google.com/search?q=womens+situat+post+indepe ndence $\&$ ie $=$ utf- $8 \&$ oe $=$ utf- 8 )

\section{References ---}

\section{Websites Used -}

1. https://www.google.com/search?q=womens+situat + post + independence $\&$ ie $=$ utf- $8 \&$ oe $=$ utf- 8

2. https://www.scribd.com/document/213644268/Wo men-Status-in-India-Before-Independence

\section{Book Used -}

1. Womens Right in India by Rekha Roy

2. Indian Feminisim by Geetanjali 